\title{
Bio-Preservation of Refrigerated Peeled Shrimp (Parapenaeus Longirostris) Using Cactus Fruit Peels Polyphenolic Extract
}

\author{
Nadia Besbes ${ }^{1}$, Jean-Jacques Joffraud ${ }^{2}$, Ines Ben Khemis ${ }^{1}$, Saloua Sadok ${ }^{1 *}$ \\ ${ }^{1}$ Laboratoire de Biotechnologie Bleue et Bioproduits Aquatiques- $B^{3}$ Aqua, Institut National des Sciences et \\ Technologies de la Mer (INSTM), 28 rue 2-mars-1934, 2025-Salammbô - Tunisia \\ ${ }^{2}$ Ifremer, Ecosystèmes Microbiens et Molécules Marines pour les Biotechnologies, F-44311 Nantes, France.
}

\begin{abstract}
The objective of this study was to evaluate the bio-preservation efficiency of polyphenols extracted from cactus fruit peels in extending the shell life of peeled shrimp during refrigerated $\left(2^{\circ} \mathrm{C}\right)$ storage. Changes in microbial, biochemical, and sensorial indicators of cactus polyphenols-treated peeled shrimp (PS) were studied comparatively to a control lot (CS). Results revealed that treatment limited biochemical degradation and reduced the final microbial load in shrimps during storage. They showed the dominance of Brochothrix and Psychrobacter within spoiling bacteria in the CS lot while only limited proliferation of Psychrobacter was observed in PS lot. Correspondence factorial analysis of sensory data showed that polyphenol-treatment extended product shelf life without altering sensorial properties. According principal component analysis, biochemical and bacterial changes were correlated positively with storage time but negatively with polyphenols treatment, which in its turn was positively correlated with sensory evaluation; confirming the beneficial effects of polyphenols treatment on shrimp bio-preservation.
\end{abstract}

Keywords: Shrimp; Bio-preservation, natural extract, shelf life, bacterial community

\section{Introduction}

In worldwide fishing industry, shrimps are generally among the resources of high economic value. The deep water rose shrimp Parapenaeus longirostris is distributed throughout the eastern Atlantic Ocean and the Mediterranean, where according FAO fishery statistics it was the most important crustacean biomass landed by trawl fisheries in 2000-2008, constituting 23\% of total crustacean regional landings (Knittweis et al., 2013). It is highly demanded in international trading markets, particularly in Europe where it is generally sold as refrigerated or frozen peeled products. Shrimp is a perishable product and postmortem changes occur rapidly compared with fish, including under cooling conditions (Zeng et al., 2005). A large variety of biochemical indicators may be used for characterization of shrimp quality and healthiness (Benner et al., 2003; Snellings et al., 2003). But as processing and in particular peeling may promote the development of a wide range of undesirable microorganisms including spoiling bacteria which lead to both health and economic concerns, microbiological indicators (Zeng et al., 2005, Dupard et al., 2006; Jiang et al., 2011; Guo et al., 2013) are also considered essential. Generally, the total number of microorganisms, as total viable counts (TVC) has been used in mandatory seafood standards and in microbiological specifications of trading agreements. However, it is known that only a small fraction of the microorganisms present on newly processed seafood is actually responsible of product spoilage and TVC may correlate poorly with the degree of freshness or remaining shelf life (Cadun et al., 2005). Therefore, characterization of microbial communities is important for providing objective quality indices to determine shelf life in seafood. For instance, the microflora of processed (chilled, cooked, peeled, packed, salted and fermented) shrimp has been largely studied using selective culture media (Mejlholm et al., 2005; Laursen et al., 2006; Han et al., 2014). Culture-independent methods are also being increasingly used to develop a complete overview of the bacterial community characteristics. Fingerprinting molecular methods, such as denaturing gradient gel electrophoresis (DGGE) and temporal temperature gradient gel electrophoresis (TTGE) are powerful tools for comparing changes in microbial communities and monitoring bacterial population dynamics (Jaffrès et al., 2009; 2011).

In shrimp, as in most seafood products, shelf life depends on the proliferation level reached during storage by the bacteria involved in spoilage. Minimizing this level and limit the environmental bacterial contamination may help processing industry to extend product shelf life. Several methods have been developed including modified atmosphere packaging (Caballero et al., 2002; Gonçalves et al., 2003; Mejlholm et al., 2005; Qian et al., 2013), the use of chemical additives (Montero et al. 2004; Gomez-Guillén et al., 2005) or a combination of both of these techniques (Thepnuan et al., 2008 ), as well as the use of bio-active packaging (Souza et al., 2015) in order to maintain qualitative proprieties and to avoid health hazards for consumers (Yerlikaya et al., 2010). In recent years bio-preservation, consisting in preventing growth of unwanted microorganisms in foodstuffs by using natural compounds, gained growing attention. Successful results are reported for proteins addition or soaking (Eakpetch et al., 2008; Kaewmanee et al., 2009), sepia soaking (Sadok 
et al., 2004), chitosan glazing or coating (Huang et al., 2012) or applications of plant extract and essential oils for coating or glazing (Nirmal and Benjakul 2010; Sundararajan et al., 2011; Maqsood et al., 2012; Zhou et al., 2013) or lactic bacteria (Calo-Mata et al., 2008; Boulares et al., 2016) on either fresh or processed fish and shrimp.

Originating from the tropical and subtropical Americas, the cactus Opuntia ficus indica was spread further by people to Africa, Asia, Europe and Australia, where more than 900000 ha of cultivated and wild plants growing in diverse agro-climatic condition provide food, forage, materials and bioactive compounds (FAO 2002). The nutritional, industrial and pharmacological valorization of the different parts (fruits, flowers and cladodes) of the plant is largely recognized and documented (FAO 2013). The succulent texture and long lasting permanence on the plant let the fruit available throughout most of the year (Jana 2012). Large amounts of biomasses are under-exploited (FAO 2002). In addition, in most of the industrial uses for the production of juices or processed beverages as well as jellies, sweeteners or jams, the thick peels are discarded (Sawaya et al., 1983) and thus constitute large amounts of by-products from which bioactive compounds could be extracted and valorized like as it is suggested for wastes from other fruits juice industries such as pears and apples (Ma et al., 2012; He et al., 2014). Objective of present study was to evaluate the efficacy of application of polyphenols extracted from cactus (Opuntia ficus indica) fruit peels in extending the shelf life of peeled shrimp (Parapenaeus longirostris) during refrigerated storage. Treatment consisted in soaking of peeled shrimp in a solution containing the polyphenols extract. Changes in biochemical, microbial and sensorial analysis of treated shrimps were studied comparatively to a control lot during refrigerated storage. The developing microbial communities were described using numeration of total aerobic viable counts on medium used for seafood analysis; as well as the PCR-TTGE method to identify and monitor the dominant bacterial populations.

\section{Preparation of polyphenols extract}

Based on previous study (unpublished data) on the optimization of polyphenols recovery from the cactus (Opuntia ficus indica) fruit peels, portions of $10 \mathrm{~g}$ of peel from fresh fruits were thoroughly minced with a mixer in $40 \mathrm{ml}$ of ice-cold ethanol/water (80:20v/v) and kept for $24 \mathrm{~h}$ of maceration under shaking conditions at $4^{\circ} \mathrm{C}$. The mixtures were then sonicated for $20 \mathrm{~min}$ and centrifuged at $10000 \mathrm{~g}$ for $15 \min$ at $4^{\circ} \mathrm{C}$. The supernatants were collected, pooled, and concentrated at $40^{\circ} \mathrm{C}$ under reduced pressure during 3 hours in a rotary evaporator (i.e. until total elimination of ethanol). To prevent oxidation of the polyphenols, the extract was conserved refrigerated in the dark and $1 \%$ aqueous solution from this extract was prepared upon needs and immediately used.

\section{Total phenolic content determination}

Phenolic compounds were assayed using the Folin-Ciocalteu reagent, following Singleton's method which was slightly modified (Singleton et al., 1999). Briefly, $0.125 \mathrm{ml}$ of a 10 -fold diluted extract was mixed with an equal volume of the Folin-Ciocalteu reagent. The mixture was shaken and allowed to stand for 6 min, before adding $1.25 \mathrm{ml}$ of $7 \%$ sodium carbonate $\left(\mathrm{Na}_{2} \mathrm{CO}_{3}\right)$ solution. The mixture was then incubated at room temperature for $45 \mathrm{~min}$ and the absorbance measured at $725 \mathrm{~nm}$. Total phenolic content (three replicates) was expressed as mg catechin equivalents (CATE)/100 $\mathrm{g}$ of fruit peel.

\section{Radical Scavenging Activity}

The antioxidant activity of the polyphenolic extract or standard pure phenolic compounds was determined using 2,2-diphenyl-1-picrylhydrazyl (DPPH) as a free radical. The reaction for scavenging DPPH radicals was performed in polypropylene tubes by adding $2 \mathrm{ml}$ of DPPH $\left(4 \times 10^{-5} \mathrm{M}\right)$ in methanolic solution to 50 $\mu \mathrm{L}$ of sample. The mixture was shaken vigorously and left for $60 \mathrm{~min}$ at room temperature. The absorbance of the resulting solution was measured at $517 \mathrm{~nm}$. Methanol was used as a blank solution, and DPPH solution without any sample extract served as control. The Trolox equivalent antioxidant capacity (TEAC) values were calculated from the equation determined from linear regression after plotting known solutions of Trolox with different concentrations $(0.02-0.8 \mathrm{mM})$. The antiradical activity was also expressed as the inhibition percentage and was calculated using the following formula: \% radical scavenging activity = (control OD - sample OD/control OD) $\times 100$.

\section{Shrimp treatment and sampling}

Fresh whole shrimp (Parapenaeus longirostris) were purchased directly from the port of Bizerte (Northern Tunisia), immediately packed in polyethylene sealed bags and transferred in ice to the laboratory where they were manually headed and peeled in sterile conditions. Processing was performed within $24 \mathrm{~h}$ after capture. The peeled shrimp were divided into two lots: shrimps of first lot were left untreated and used as control (C) while those of second lot were soaked $5 \mathrm{~min}$ in distilled/sterilized water containing dilute (1/10) cactus phenol solution $(\mathrm{P})$. The ratio of fish to soaking solution was $1 / 10(\mathrm{w} / \mathrm{v})$. Each lot $(\mathrm{C}$ and $\mathrm{P})$ was 
subdivided into 10 portions of $100 \mathrm{~g}$ (consisting in about 20 specimens) which were directly vacuum packaged in pouches of polyethylene and immediately stored at $2{ }^{\circ} \mathrm{C}$. Sampling was undertaken after 0, 3, 5, 7 and 9 days of storage. Two pouches from each lot were randomly selected and analyzed in triplicates each sampled pouch (thus $\mathrm{n}=6$ for each sampling day and treatment).

\section{Lipid extraction and fatty acid analysis}

\section{Chemical analysis}

Total lipids were extracted according to the method of Folch et al., (1957) and were expressed in g/100 $\mathrm{g}$ wet weight. They were made soluble in Vorbeck solution (Toluene- ethanol (4:1 v/v) (Metcalfe et al.,. 1966) and stored at $-40{ }^{\circ} \mathrm{C}$ until analysis of fatty acids as fatty acids methyl esters (FAMEs) described by Metcalfe et al., (1966). A fraction of the lipid extract was saponified with $0.5 \mathrm{~mol} / \mathrm{L} \mathrm{NaOH}$ in methanol, followed by a methylation in $12 \%$ boron trifluoride in methanol $\left(\mathrm{BF}_{3} / \mathrm{MeOH}\right)$. The methylated sample was then extracted with n-hexane. Analysis were performed on the non spoiled shrimps and limited to the three first sampling days (i.e. at 0, 3 and 5 days of storage). The FAMEs were resolved using an Agilent-Technologies chromatograph 6890N (Palo Alto, CA, USA having a flame ionization detector (FID), a splitless injector and a polar INNOWAX $30 \mathrm{M}$ silica capillary column $(0.25 \mathrm{~mm}$ i.d. \& $0.25 \mu \mathrm{m}$ film thickness $)$. The temperature of the injector was $220^{\circ} \mathrm{C}$ and that of the detector $\mathrm{w}$ was $275^{\circ} \mathrm{C}$. Helium at a flow rate of $1.5 \mathrm{ml} / \mathrm{min}$ was used as the carrier. Peaks of chromatograms were identified by comparison to a standard mixture (SUPELCO-47085-U Sigma-Aldrich) containing 19 FAMEs. The values are given as percentages of the total FAMEs.

\section{Biochemical indicators of quality}

The nitrogenous compounds in samples of flesh as well as the peroxidation indicators in lipids were studied throughout storage.

The analyzed nitrogenous compounds consisted in total volatile basic nitrogen (TVB), trimethylamine (TMA) and total free amino acid measured as ninhydrin positive substances (NPS). They were determined by flow injection analysis (FIA) according to the methods of Ruiz-Capillas \& Horner (1999), Sadok et al., (1996) and Sadok et al., (1995) respectively.

The peroxide value (PV) was determined according to the ferric thiocyanate method with slight modification (Chapman and Mckay, 1949). Fractions of 50 to $100 \mathrm{mg}$ from lipid extract were homogenized for $2 \mathrm{~min}$ at $2000 \mathrm{rpm}$ in a final volume of $10 \mathrm{ml}$ of a chloroform/methanol mixture (7:3). Then $50 \mathrm{ml} \mathrm{of}$ ammonium thiocyanate $(10 \mathrm{mM})$ solution and $2 \mathrm{ml}$ of ferrous chloride solution $(10 \mathrm{mg} / \mathrm{ml}$ iron III) were added and mixed for $1 \mathrm{~min}$ at $2000 \mathrm{rpm}$. After an incubation of $5 \mathrm{~min}$ at room temperature the absorbance was measured at $500 \mathrm{~nm}$ against a blank and a standard curve. The results were expressed in terms of meq of oxygen per $\mathrm{kg}$ of oil.

The acid reactive substances in lipids were determined as thiobarbyturic acid reactive substances (TBARs) according to the AOAC (1998) method, which allows their determination without preliminary isolation of secondary oxidation products (Attouchi and Sadok 2010). Fractions of 50 to $200 \mathrm{mg}$ from lipid extract were diluted in $10 \mathrm{ml}$ of 1-butanol and mixed with $10 \mathrm{ml}$ of $0.2 \%$ thiobarbyturic acid (TBA) in 1-butanol before an incubation of $2 \mathrm{~h}$ at $95^{\circ} \mathrm{C}$. After cooling for $10 \mathrm{~min}$ under running tap water, the absorbencies were measured at $532 \mathrm{~nm}$ against a blank and a standard curve determined by the TBARs reaction of aliquots $(0.1$ to $1 \mathrm{ml}$ ) of $0.2 \mathrm{mM}$ 1,1,3,3-tetramethoxypropane (TMP) in 1-butanol. Results were expressed as $\mathrm{mg}$ malonaldehyde (MA)/kg of fresh weight.

\section{Enumeration of total aerobic viable bacteria}

\section{Microbial analysis}

For bacterial analysis, 15 -g portions from each sampled pouch was aseptically weighed and pooled per treatment into $120 \mathrm{ml}$ of sterile physiological saline solution $(0.85 \% \mathrm{NaCl})$ with $0.1 \%$ peptone in a sterile plastic bag. This pooled samples were blended with a stomacher 400 (Seward-Medical, London, UK) for 2 min. After $30 \mathrm{~min}$ at room temperature for bacterial resuscitation, $30 \mathrm{ml}$ of each blend were pooled into a sterile vial and thoroughly mixed to constitute the homogenized analysis solution. Several appropriate 10-fold dilutions of this solution were carried out in sterile physiological saline solution and triplicates of $0.1 \mathrm{ml}$ of each were spread on plates containing on Long and Hammer agar (LH) with $1 \% \mathrm{NaCl}$ (Macé et al., 2012). The total aerobic viable counts (TAVC) were determined after each 2 days of incubation at at $20^{\circ} \mathrm{C}$ (Van Spreekens, 1974).

\section{Biochemical characterization of bacterial isolates}

When shrimp samples were considered as spoiled, approximately 25 to 30 isolates were randomly selected by picking colonies from LH plates of the highest dilution showing growth. These isolates were collected and purified twice on brain heart infusion agar (BHI Biokar-Diagnostic, Beauvais, France) and then 
each isolate was examined for motility, Gram reaction with KOH (Gregersen 1978), catalase activity by the 3\% $\mathrm{H}_{2} \mathrm{O}_{2}$ method and cytochrome oxidase production by Bactident-Oxidase reagent (Merck, Darmstadt, Germany).

\section{Molecular identification of bacterial isolates}

In order to characterize the isolates at species or genus level, molecular tests based on polymerase chain reaction (PCR) were used. The chromosomal DNA of the isolated strains was extracted using the Qiagen DNeasy Tissue Kit (Courtaboeuf, France) and oligo-nucleotide PCR obtained from Invitrogen (Cergy Pontoise, France).

For each strain or group of strains identified as belonging to a bacterial species or genus, the 16S rDNA gene was partially sequenced (about $700 \mathrm{bp}$ ) for one or several representative, depending on the group size. The 16S rDNA was amplified using the sequences of oligonucleotide primers pairs fD1 and rD1 (Table 1), as described in Macé et al., (2012). The nucleotide sequence of the amplified 16S rDNA was partially determined with an automated sequencer (Beckman Coulter Genomics, Takeley, UK). The sequences were then submitted to the National Center for Biotechnology Information (NCBI, Bethesda, USA, http://www.ncbi.nlm.nih.gov/). The computer program CLUSTAL W (Thompson et al., 1994) was used for sequence alignment and the Basic Local Alignment Search Tool 2 program (BLAST) for representation of sequence and similarity searches in the GenBank database.

\begin{tabular}{|l|l|l|c|c|}
\hline Primer & \multicolumn{1}{|c|}{ Position } & Oligonucleotide sequence (5'-3') & $\begin{array}{l}\text { Annealing } \\
\left({ }^{\circ} \mathrm{C}\right)\end{array}$ & Reference \\
\hline fD1 & $\begin{array}{l}\text { 16S rDNA gene, } \\
\text { forward (positions 8-27) }\end{array}$ & AGAGTTTGATCCTGGCTCAG & 56 & $\begin{array}{l}\text { Weisburg et } \\
\text { al. [1991] }\end{array}$ \\
\hline rD1 & $\begin{array}{l}\text { 16S rDNA gene, reverse } \\
\text { positions 1525-1542) }\end{array}$ & TAAGGAGGTGATCCAGCC & 56 & $\begin{array}{l}\text { Weisburg et } \\
\text { al.[1991] }\end{array}$ \\
\hline V3P2 & $\begin{array}{l}\text { 16S rDNA gene, } \\
\text { forward (positions 517- } \\
\text { 533). }\end{array}$ & ATTACCGCGGCTGCTGG & $\begin{array}{l}\text { Parayre et } \\
\text { al.[2007] }\end{array}$ \\
\hline V3P3 & $\begin{array}{l}\text { 16S rDNA gene, } \\
\text { forward (positions 340- } \\
356)\end{array}$ & $\begin{array}{l}\text { CGCCCGCCGCGCGCGGCGGGCGG } \\
\text { GGCGG }\end{array}$ & 62 & $\begin{array}{l}\text { Parayre et } \\
\text { al.[2007] }\end{array}$ \\
\hline & $\begin{array}{l}\text { GGGCACGGGGGCCTACGGGAGGC } \\
\text { AGCAG }\end{array}$ & & \\
\hline
\end{tabular}

Table 1: Sequences of oligonucleotide primers used for PCR amplification of bacteria strain isolated from shrimp.

\section{Molecular identification from shrimp matrix direct bacterial DNA extraction}

Temporal temperature gradient gel electrophoresis (TTGE) analysis was performed using the homogenized solution, prepared for the enumeration of inoculated strains was used to extract bacterial DNA, directly from the shrimp matrix, detailed by Jaffrès et al., (2009). Bacterial DNA extract was analysed by PCRTTGE. Primers V3P2 and V3P3 GC-Clamp (Parayre et al., 2007) (Table 1) were used to amplify 16 S rRNA V3 region (194bp) by PCR as described previously (Jaffrès et al., 2009). The size of the PCR products was determined in a $1.5 \%(\mathrm{w} / \mathrm{v})$ agarose gel (Invitrogen) using a PCR DNA ladder (Fisher Scientific, Illkirch, France).The PCR products obtained from the V3 16S rDNA fragment amplification were subjected to TTGE analysis performed as described by Jaffres et al. (2009). Standardization, analysis and comparison of TTGE fingerprints were monitored using BioNumerics Software, version 6.0 (Applied Maths NV, Sint-Martens-Latem, Belgium).

\section{Sensory analysis}

Sensory analysis was conducted by a taste panel consisting of 80 Tunisian consumers gathered during a National Seafood Exhibition. Treated and control shrimps were individually coded and randomly presented to panelists who shared samples. A four-point hedonic scale was used for rating: $1=$ low, $2=$ lightly, $3=$ moderate and $4=$ high quality (Peryam \& Pilgrim, 1957) according to its spoilage level (SS: strongly spoiled, LS: lightly spoiled, MS: moderately spoiled, NS: non-spoiled). Panelists were instructed to consume the whole sample and to rinse their mouth with water between samples to minimize any residual effect. Sensory assessment included the following parameters: taste, astringency, color, odor and firmness. Sour odor and firmness loss were chosen as being directly related to autolysis development and astringency as indicating a marked polyphenolic character. 


\section{Statistical analysis}

For each lot and at each sampling time, the results were presented as mean \pm standard deviation (SD) of $\mathrm{n}=6$ and were analyzed using two-way analysis of variance (ANOVA) using time and treatments as variables along with their interaction effect. Tukey procedure was applied for post hoc comparisons of the data with a significance level fixed at $5 \%$. Results of sensory analysis were first submitted to a correspondence factorial analysis (CFA). Finally, all the data were also analyzed by principal component analysis (PCA). Leverage correction was applied to all the data. Variables were weighted with the inverse of the standard deviation of all data in order to compensate for their different scales. Martens Uncertainty test was used to examine the influence of considered variables on the treatment with polyphenols. Statistics were performed using XL-stat software

\section{Results And Discussion}

Many food preservation strategies can be used for the control of microbial spoilage and oxidation but even if synthetic antimicrobial and antioxidant agents are approved in many countries, the use of natural safe and effective preservatives is a demand of food consumers and producers (Ortega-Ramirez et al., 2014). Cactus pear (Opuntia spp.) cladodes and fruits are rich in bio-active compounds among which polyphenols are the most important (Feugang et al., 2006). Polyphenols, include a large variety of molecules such as flavonoids, betalains and tannins, which are natural secondary metabolites subject of intense investigations owing to their wide spectrum of biological activities which include in particular strong antioxidant and antimicrobial effects (Azeredo, 2009; FAO, 2013). The -OH groups in the phenolic compounds are thought to be largely responsible for these actions (Gelssman, 1963). In present study, polyphenols extracted from cactus fruits peels were used for treatment of peeled shrimp and the effects on biochemical, microbial and sensorial changes during refrigerated storage were studied comparatively to a control lot.

\section{Total polyphenolic content and antioxidant activity of cactus fruit peel extract}

The total polyphenolic content of the cactus pear peel extract was $1472 \pm 7 \mathrm{mg}$ per $100 \mathrm{~g}$ of fruit peel. The cactus fruit peel extracts showed a much higher polyphenol proportions compared to the extracts of Opuntia cactus fruit pulp ( $909.47 \pm 29.34 \mathrm{mg} / \mathrm{l}$ and $15.34 \pm 0.73 \mathrm{mg} / \mathrm{kg}$ respectively) found in others studies (Khatabi et al., 2011). As expected and in agreement with the strong correlation reported between antioxidant activity and phenolic content in cactus fruit extracts (Butera et al., 2002), the peel extract also showed a strong antioxidant activity with an average value of $100 \mu \mathrm{mol} \pm 0.015$ of TEAC/g fw which represent 4 to 20 fold stronger source of antioxidants when compared to the pulp, for which values ranged from 4.20 to $26.3 \mu \mathrm{mol}$ TEAC/g of fresh weight as reported by Butera et al., (2002).

\section{Changes in lipid content and in fatty acids composition}

The lipid content of the control and treated shrimp during refrigerated storage are presented Fig.1. Initial lipid content of the shrimp P. longirostris showed an average value of $0.54 \pm 0.04 \mathrm{~g} / 100 \mathrm{~g}$. It is within the range of expected values for this species. Indeed, lipid content is reported to range between 0.3 and $3.2 \%$ according to Oksuz et al. (2009) with a value of $0.3 \%$ for autumn. Cadun et al. (2005) and Huidobro et al. (2002) also found values of 0.35 and $0.31 \%$ for frozen shrimps and shrimps covered with liquid ice respectively.

During refrigerated storage, a marked decrease in lipid content was observed in the flesh of both experimental lots; with however distinct profile as decrease was faster and reached a lower level in untreated shrimp lot. Such a decrease is commonly observed during storage of seafood products. This is due to their enzymatic and bacterial degradation according to Chaijan et al. (2006). The different changes observed between the two shrimp lots clearly indicate that polyphenols treatment showed preserving effect on lipids during storage. Such effect could be due to the inhibition of enzymatic and bacterial degradation of shrimp lipid by polyphenols. It is well known that polyphenols may react with protein to give complex (Richard et al., 2006). Such complex formed at the surface of flesh may act as a barrier inhibiting the loss of liquids, including water and lipids as reported in sea bream fillets treated with aromatic plants rich in polyphenolic compounds (Attouchi and Sadok, 2010). It may be supposed that a similar phenomenon occurred in shrimps of polyphenols treated lot of present study. 


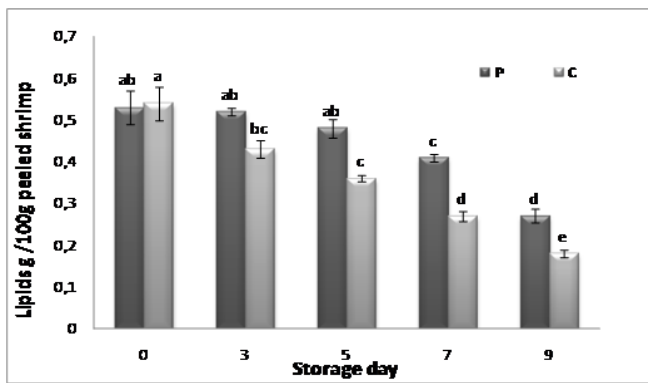

Figure 1: Flesh total lipid content in Control (C) and Polyphenol (P) Treated shrimp during various periods of refrigerated storage $\left(2^{\circ} \mathrm{C}\right)$. Data are mean \pm Standard Deviation, $(\mathrm{N}=6$; In Each Case). Values with different superscript letters are significantly different $(\mathrm{P}<0.05)$.

Total fatty acids (FA) compositions of lipids are presented in Table 2. In both lots, saturated fatty acids (SFA) represented the major type of fatty acids followed by polyunsaturated (PUFA) and monounsaturated fatty acids (MUFA). Within SFA, the major FAs were palmitic acid C16:0, stearic acid C18:0 while in MUFA the major FAs were palmitoleic acid C16:1 n-7 and oleic acid C18:1 n-9. The three major PUFA consisted in DHA - docosahexaenoic acid C22:6(n-3), EPA - eicosapentaenoic acid C20:5(n-3) and ARA - arachidonic acid C20:4 $\mathrm{n}-6$. As expected, FA profiles of both lots were similar at the beginning of the experiment. During storage, marked changes appeared in control lot, consisting mainly in a significant $(p<0.05)$ decrease in PUFA levels with a concomitant increase in SFA levels while only minor changes appeared in treated lot, with no incidence on relative composition of FA types. These results are clearly indicating that the polyphenolic treatment had preservative effects on PUFAs of peeled shrimps. Similar preservative effects of natural polyphenols, extracted from quince fruit (Cydonia oblonga Miller), were reported recently in a study concerning their use freshwater mullet (Mugil cephalus) smoked fillets refrigerated during 75 days (Bouzgarrou et al., 2015).

Table 2: Fatty Acids composition of Control (C) and polyphenol treated peeled (P) shrimp following various periods of refrigerated storage $\left(+2^{\circ} \mathrm{C}\right)$ at Day 0,3 and 5. Sfa: Saturated Fatty Acid; Mufa: Monounsaturated Fatty Acid; Pufa: Polyunsaturated Fatty Acid; Others: C15:0, C17:0, C19:0. Data Are Mean \pm Standard Deviation, (N=3).

\begin{tabular}{|c|c|c|c|c|c|c|}
\hline \multirow[t]{3}{*}{ Fatty Acids } & \multirow{2}{*}{\multicolumn{2}{|c|}{$\begin{array}{c}\text { Storage time } \\
(0 \text { days })\end{array}$}} & \multirow{2}{*}{\multicolumn{2}{|c|}{$\begin{array}{l}\text { Storage time } \\
\text { after } 3 \text { days }\end{array}$}} & \multirow{2}{*}{\multicolumn{2}{|c|}{$\begin{array}{l}\text { Storage time } \\
\text { after } 5 \text { days }\end{array}$}} \\
\hline & & & & & & \\
\hline & \multicolumn{2}{|c|}{ C O $\quad$ P O } & \multicolumn{2}{|c|}{ C3 P 3 } & \multicolumn{2}{|c|}{ P 5} \\
\hline (C14:0) & $0.00^{\mathrm{a}}$ & $0.00^{\mathrm{a}}$ & $0.00^{\mathrm{a}}$ & $0.00^{\mathrm{a}}$ & $0.00^{\mathrm{a}}$ & $0.00^{\mathrm{a}}$ \\
\hline (C16:0) & $35.36^{\mathrm{a}}$ & $34.07^{\mathrm{a}}$ & $40.36^{\mathrm{b}}$ & $37.95^{\mathrm{a}, \mathrm{b}}$ & $40.79^{\mathrm{b}}$ & $38.17^{\mathrm{b}}$ \\
\hline (C18:0) & $18.15^{\mathrm{a}, \mathrm{b}}$ & $14.44^{\mathrm{a}}$ & $18.77^{\mathrm{b}}$ & $14.62^{\mathrm{a}}$ & $18.77^{\mathrm{b}}$ & $14.80^{\mathrm{a}}$ \\
\hline (C16:1 n-7) & $3.99^{\mathrm{a}}$ & $4.06^{\mathrm{a}}$ & $4.85^{\mathrm{a}, \mathrm{b}}$ & $4.71^{\mathrm{a}}$ & $4.24^{\mathrm{a}}$ & $5.96^{\mathrm{b}}$ \\
\hline (C16:3 n-4) & $1.33^{\mathrm{a}, \mathrm{b}}$ & $1.6^{\mathrm{a}}$ & $1.3^{\mathrm{b}}$ & $1.57^{\mathrm{a}}$ & $1.24^{\mathrm{b}}$ & $1.42^{\mathrm{a}}$ \\
\hline (C18:1 n-9) & $16.42^{\mathrm{a}}$ & $15.54^{\mathrm{a}}$ & $14.33^{\mathrm{a}, \mathrm{b}}$ & $15.53^{\mathrm{a}}$ & $12.27^{\mathrm{b}}$ & $14.18^{\mathrm{a}, \mathrm{b}}$ \\
\hline (C18:1 n-7) & $2.60^{\mathrm{a}}$ & $2.34^{\mathrm{a}}$ & $3.07^{\mathrm{a}}$ & $3.01^{\mathrm{a}}$ & $2.47^{\mathrm{a}}$ & $2.38^{\mathrm{a}}$ \\
\hline (C18:2 n-6) & $2.29^{\mathrm{a}}$ & $1.62^{\mathrm{a}}$ & $1.56^{\mathrm{a}}$ & $1.60^{\mathrm{a}}$ & $1.32^{\mathrm{b}}$ & $1.59^{\mathrm{a}}$ \\
\hline (C18:3 n-3) & $0.00^{\mathrm{a}}$ & $0.00^{\mathrm{a}}$ & $0.00^{\mathrm{a}}$ & $0.00^{\mathrm{a}}$ & $0.00^{\mathrm{a}}$ & $0.00^{\mathrm{a}}$ \\
\hline (C18:4 n-3) & $0.00^{\mathrm{a}}$ & $0.00^{\mathrm{a}}$ & $0.00^{\mathrm{a}}$ & $0.00^{\mathrm{a}}$ & $0.00^{\mathrm{a}}$ & $0.00^{\mathrm{a}}$ \\
\hline$(\mathrm{C} 20: 4$ n-6) & $3.32^{\mathrm{a}}$ & $3.44^{\mathrm{a}}$ & $3.25^{\mathrm{a}}$ & $3.31^{\mathrm{a}}$ & $3.05^{\mathrm{a}}$ & $3.22^{\mathrm{a}}$ \\
\hline (C20:5 n-3)EPA & $9.38^{\mathrm{a}}$ & $9.32^{\mathrm{a}}$ & $8.41^{\mathrm{a}}$ & $8.99^{\mathrm{a}}$ & $7.75^{\mathrm{b}}$ & $8.65^{\mathrm{a}}$ \\
\hline$($ C22:5 n-3) & $0.00^{\mathrm{a}}$ & $0.00^{\mathrm{a}}$ & $0.00^{\mathrm{a}}$ & $0.00^{\mathrm{a}}$ & $0.00^{\mathrm{a}}$ & $0.00^{\mathrm{a}}$ \\
\hline (C22:6 n-3)DHA & $8.33^{\mathrm{a}}$ & $8.29^{\mathrm{a}}$ & $6.41^{\mathrm{b}}$ & $7.82^{\mathrm{a}}$ & $6.41^{\mathrm{b}}$ & $7.69^{a}$ \\
\hline SFA & $53.51^{\mathrm{a}}$ & $48.51^{\mathrm{a}}$ & $59.14^{b}$ & $52.57^{\mathrm{a}}$ & $54.55^{\mathrm{a}}$ & $52.96^{\mathrm{a}}$ \\
\hline MUFA & $19.95^{\mathrm{a}}$ & $16.76^{\mathrm{a}}$ & $21.22^{\mathrm{a}}$ & $21.24^{\mathrm{a}}$ & $18.16^{\mathrm{a}}$ & $19.80^{\mathrm{a}}$ \\
\hline PUFA & $23.00^{\mathrm{a}}$ & $23.74^{\mathrm{a}}$ & $19.64^{b}$ & $21.71^{\mathrm{a}}$ & $18.94^{b}$ & $22.10^{\mathrm{a}}$ \\
\hline $\mathrm{n}-3$ & $17.71^{\mathrm{a}}$ & $17.61^{\mathrm{a}}$ & $14.83^{\mathrm{b}}$ & $16.81^{\mathrm{a}}$ & $14.15^{b}$ & $16.43^{\mathrm{a}}$ \\
\hline$n-6$ & $4.84^{\mathrm{a}}$ & $5.07^{\mathrm{a}}$ & $4.81^{\mathrm{a}}$ & $4.91^{\mathrm{a}}$ & $4.37^{\mathrm{a}}$ & $4.82^{\mathrm{a}}$ \\
\hline
\end{tabular}

${ }^{\mathrm{a}-\mathrm{e}}$ Means within the same row with different superscripts indicate significant differences $(\mathrm{p}<0.05)$.

\section{Changes in biochemical indicators of quality}

Changes in biochemical indicators of quality throughout storage are compiled in Table 3. Initial PV levels were similar for both experimental lots with a value of 0.25 meq active $\mathrm{O}_{2} / \mathrm{kg}$ oil. It increased significantly during storage to reach $1.07 \mathrm{meq} \mathrm{O}_{2} / \mathrm{kg}$ oil in the shrimp of control lot at the end of the experiment. The shrimp treated with polyphenols showed significantly $(\mathrm{p}<0.05)$ lower final PV level $\left(0.7 \mathrm{meq}_{2} / \mathrm{kg}\right.$ oil $)$ than did the control lot, reflecting a reduced lipid oxidation related to treatment effect. The initial values of 
TBARs in control and treated shrimp lipid were 0.53 and $0.51 \mathrm{mg} \mathrm{MA} / \mathrm{kg}$ oil respectively. These values are low and emphasize the excellent quality and freshness of the starting material. Similarly to PV trends, during refrigerated storage TBARs levels increased significantly $(\mathrm{p}<0.05)$ in peeled shrimp of the two lots but in a lower extent in polyphenols-treated shrimp. Thus pattern of changes of TBARs clearly showed that cactus fruit peel polyphenols exhibited significant antioxidant properties and were able to retard lipid oxidation in flesh of peeled shrimps during the 9 days of refrigerated-storage. Indeed, TBARs levels quantify the accumulation of secondary products of oxidation which are formed along time. The lipid oxidation occurring in peeled shrimps during refrigerated storage is generally due to the high content of unsaturated fatty acids and pro-oxidants in the muscle, (Oksuz et al., 2009). Indeed, it is admitted that relatively high levels of PUFA with important numbers of double bounds in the lipid fraction determine susceptibility of flesh oxidation (Chaijan et al., 2006). It may be supposed that bioactive compounds migrate from the aqueous solution of polyphenols extract to shrimp flesh surface they are adsorbed and act as free radical scavengers. Globally, results of both PV and TBARs showed that cactus-polyphenols exhibited significant antioxidant properties and that the treatment limited and retarded lipid oxidation in peeled shrimps. These results are additional proofs of preservative action of the polyphenols treatment.

Table 3: Changes in Total Volatile Base Nitrogen (TVB), Trimethylamine (TMA), Total Free Amino Acids as ninhydrin positive substances (NPS), Peroxide Value (PV) and Thiobarbyturic Acid (TBARS) in Control (C) and Polyphenols-Treated Peeled Shrimps (P) during various periods of refrigerated storage $\left(2^{\circ} \mathrm{C}\right)$. Data are Mean \pm Standard Deviation, $(\mathrm{N}=6)$.

\begin{tabular}{|c|c|c|c|c|c|c|}
\hline Days & & $\mathbf{0}$ & 3 & 5 & 7 & 9 \\
\hline PV & $\mathbf{C}$ & $0.32 \pm 0.04 \mathrm{a}$ & $0.68 \pm 0.03 \mathrm{~d}$ & $0.67 \pm 0.30 \mathrm{~cd}$ & $0.96 \pm 0.06 \mathrm{e}$ & $1.07 \pm 0.06 \mathrm{e}$ \\
\hline (meq active $\mathrm{O}_{2} / \mathrm{kg}$ oil) & $\mathbf{P}$ & $0.25 \pm 0.04 \mathrm{a}$ & $0.46 \pm 0.02 \mathrm{abc}$ & $0.45 \pm 0.02 \mathrm{ab}$ & $0.60 \pm 0.02 \mathrm{bcd}$ & $0.73 \pm 0.05 \mathrm{~d}$ \\
\hline TBARS & $\mathbf{C}$ & $0.53 \pm 0.02 \mathrm{a}$ & $0.93 \pm 0.02 \mathrm{~cd}$ & $1.54 \pm 0.06 \mathrm{~g}$ & $1.68 \pm 0.04 \mathrm{gh}$ & $1.79 \pm 0.02 \mathrm{~h}$ \\
\hline (mg MA/kg oil) & $\mathbf{P}$ & $0.51 \pm 0.01 \mathrm{a}$ & $0.73 \pm 0.05 \mathrm{~b}$ & $0.85 \pm 0.01 \mathrm{bc}$ & $0.99 \pm 0.01 \mathrm{de}$ & $1.34 \pm 0.02 \mathrm{f}$ \\
\hline TVB-N & $\mathbf{C}$ & $11.49 \pm 0.24 \mathrm{ab}$ & $15.54 \pm 0.22 \mathrm{c}$ & $21.68 \pm 0.24 \mathrm{e}$ & $28.83 \pm 0.14 \mathrm{f}$ & $32.07 \pm 0.22 \mathrm{~g}$ \\
\hline (mg/100g) & $\mathbf{P}$ & $10.85 \pm 0.31 \mathrm{a}$ & $12.19 \pm 0.30 \mathrm{~b}$ & $15.96 \pm 0.24 \mathrm{c}$ & $18.35 \pm 0.29 \mathrm{~d}$ & $22.12 \pm 0.29 \mathrm{e}$ \\
\hline TMA-N & $\mathbf{C}$ & $0.27 \pm 0.08 \mathrm{ab}$ & $1.75 \pm 0.10 \mathrm{~d}$ & $3.83 \pm 0.17 \mathrm{f}$ & $4.43 \pm 0.10 \mathrm{~g}$ & $5.92 \pm 0.06 \mathrm{~h}$ \\
\hline$(\mathrm{mg} / \mathbf{1 0 0 g})$ & $\mathbf{P}$ & $0.21 \pm 0.03 \mathrm{a}$ & $0.43 \pm 0.04 \mathrm{~b}$ & $1.07 \pm 0.05 \mathrm{c}$ & $2.06 \pm 0.04 \mathrm{~d}$ & $3.04 \pm 0.11 \mathrm{e}$ \\
\hline NPS & $\mathbf{C}$ & $0.58 \pm 0.01 \mathrm{a}$ & $1.34 \pm 0.05 \mathrm{c}$ & $1.47 \pm 0.06 \mathrm{~cd}$ & $1.68 \pm 0.04 \mathrm{de}$ & $1.87 \pm 0.02 \mathrm{e}$ \\
\hline$(\mathrm{mM} / 100 \mathrm{~g})$ & $\mathbf{P}$ & $0.58 \pm 0.01 \mathrm{a}$ & $0.67 \pm 0.02 \mathrm{ab}$ & $0.68 \pm 0.03 \mathrm{ab}$ & $0.81 \pm 0.03 \mathrm{~b}$ & $1.38 \pm 0.07 \mathrm{c}$ \\
\hline
\end{tabular}

Levels of TVB of both control and polyphenols treated lots remained below the European Commission (CEC, 1995) limit (35 mg-N TVB $100 \mathrm{~g}^{-1}$ ). Nevertheless, polyphenols treated lot showed significantly lower levels comparatively to control, indicating that the treatment produced an obvious preservative effect on peeled shrimps. There is no regulation concerning the TMA level in crustacean but, beyond $12 \mathrm{mg}-\mathrm{N}$ TMA $100 \mathrm{~g}^{-1}$ the product quality is generally considered damaged. Similarly to TVB, throughout storage TMA levels of both control and polyphenols treated lots did not exceed this limit and polyphenols treated lot showed significantly lower levels comparatively to control. After 5 and 9 days of storage, when the control and treated batch were rejected by the panelists, none of the lots exceeded this limit. Thus, results indicate that levels of TVB or TMA are not closely linked to the sensory quality of refrigerated peeled shrimp. During the entire refrigerated storage, NPS level of control lot was significantly $(\mathrm{p}<0.05)$ higher than that of polyphenols treated lot. Free amino acids are produced in fish and shellfish as a result of muscle proteolysis and spoilage progress while tissues serve as a substrate for microbial growth (Ruiz-Capillas \& Moral, 2003). These results further confirm preservative action of polyphenols treatment and reveal that it is also related to antibacterial properties of its bio-active compounds which seem effective against shrimp spoiling bacteria.

\section{Sensory analysis}

Using the four-point hedonic scale, initially nearly similar patterns of percentages were observed in each sensorial attribute for treated and non- treated samples, which exhibited high scores quality. In order to obtain a better understanding of changes of the different quality parameters during storage; the systematic structure in the sensory data was studied by the correspondence factorial analysis (CFA). Together, the first two factorial axes allowed restoration of around $90.37 \%$ of the total information (Fig.2). The first and second axis, which restored $77.75 \%$ and $12.62 \%$ of the total information respectively, allowed the separation of stronglyspoiled SS samples (right part of Fig.2) from non-spoiled NS samples (left part of Fig.2). For instance, control samples (C0) and polyphenols-treated samples (P0 and P3) were located in the NS area; whereas control samples (C5) and treated-shrimp samples (P9) were located in the SS area. Lightly-spoiled LS and moderatelyspoiled MS were grouped in intermediate areas. Along storage, changes in sensorial attributes of samples 
showed a progressive shift throughout these grouping categories with faster changes for the control comparatively to treated lot. Thus the sensorial results clearly demonstrate that the use of polyphenols extract extended the shelf life of shrimp without altering their initial sensorial properties.

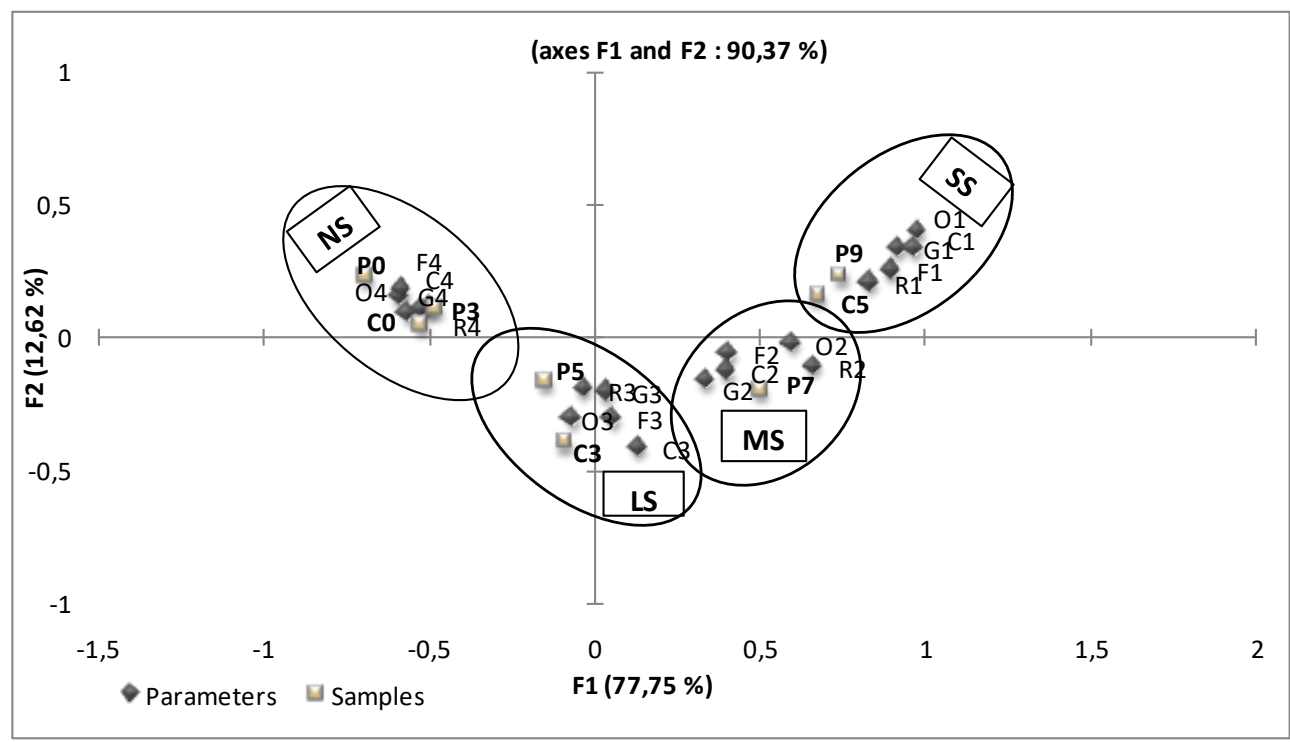

Figure 2: Simultaneous representation of samples and spoilage levels of shrimp samples during various periods of refrigerated Storage $\left(2^{\circ} \mathrm{C}\right)$. On Plane 1-2 Of Correspondence Factorial Analysis (CFA). Ns: Non-Spoiled; Ls: Lightly Spoiled; Ms: Moderately Spoiled; Ss: Strongly Spoiled. Sample Nomenclature: C, Control Samples (Non-Treated); P, Treated Sample With Polyphenol. Number Express Duration of Storage (Days). Sensorial Parameters: F: Firmness, G: Taste, O: Odor, R: Astringency, C: Color.

\section{Microbial analysis}

Initially, control and treated lots displayed total aerobic viable counts (TVC) of $3.7 \mathrm{Log}-\mathrm{CFU} \mathrm{g}{ }^{-1}$ and 3.8 $\mathrm{Log}_{\text {-CFU g }}{ }^{-1}$ respectively (Fig.3). During refrigerated storage, the control lot showed a faster microbial development with a TVC value reaching $6.5 \mathrm{Log}^{-\mathrm{CFU} \mathrm{g}}{ }^{-1}$ after 5 days of storage and thus already overcoming the upper acceptable limit $\left(5 \mathrm{Log}_{-} \mathrm{CFU} \mathrm{g}{ }^{-1}\right)$ which was overcome after 9 days in the polyphenols-treated lot $(5,4$ $\log -\mathrm{CFU} \mathrm{g}{ }^{-1}$ ). The spoilage depends not only on the level of contamination but also on which microorganisms are present on the product. Indeed, microflora of spoiled products consist in a mix of microorganisms that have actively contributed to the spoilage, called Specific Spoilage Organisms (SSO), and microorganisms that have grown without affecting the sensory quality (Gram et al., 2002). Modifying this assemblage of microorganisms and their development may impact product shelf life.

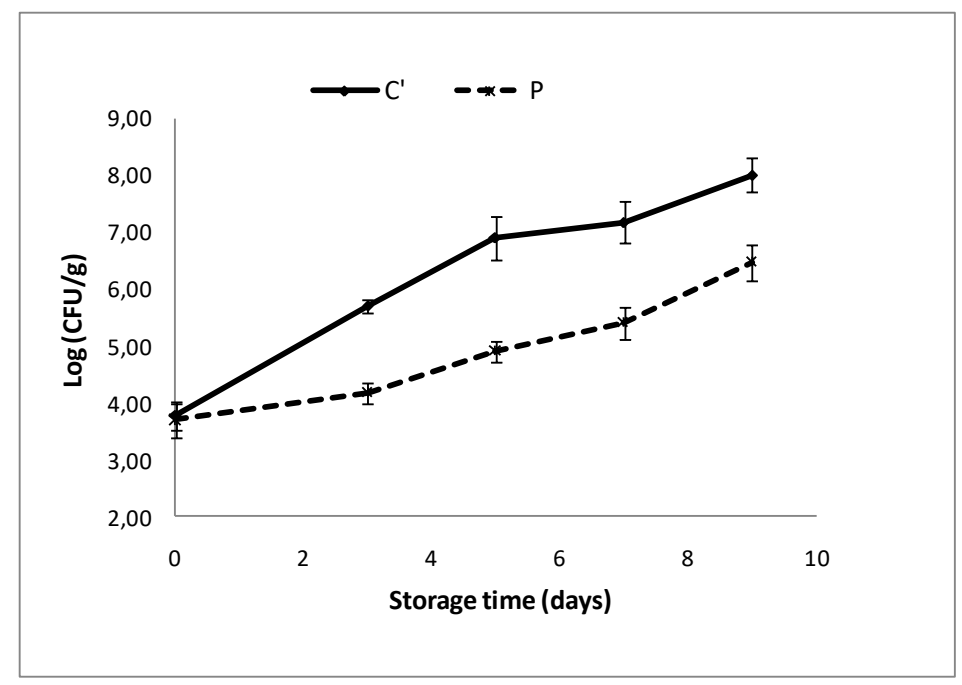

Figure 3: Bacterial growth evolution in Total Aerobic Viable Count (TAVC), of Control (C) and Treated shrimps $(\mathrm{P})$ during various periods of refrigerated Storage $\left(2^{\circ} \mathrm{C}\right)$. Values with different superscript letters are significantly different $(\mathrm{P}<0.05)$. 
The bacterial isolates obtained from control and treated samples were divided into two main groups based on phenotypic tests (Gram reaction, oxidase, catalase). The first consisted in Gram negative and oxidase positive bacterias while the second groups consisted in Gram positive and catalase negative bacterias. Using total 16S rRNA gene sequencing, the strains isolates were identified with $98-100 \%$ sequence identity as Carnobacterium, Psychrobacter and Brochothrix. The TTGE analysis enabled the visualization microbiota dynamics by examining fingerprints of dominating bacterial groups evolving during storage (Fig.4). In order to analyze TTGE patterns and to detect the bacterial species, fingerprints of the different samples were compared with those of pure strains of Carnobacterium, Psychrobacter, Brochothrix, isolated from both C and CP lots. The TTGE profiles of shrimp samples during storage revealed 5 different major bands (A to E) among which three bands could be confirmed as corresponding to Brochothrix (band D), Psychrobacter (band C) and Carnobacterium (band B) by comparing the band migration position to that of the reference strain profiles. The two other bands (A and E) were unassigned and were considered as bands related to unknown strains. At beginning of analysis, TTGE profiles of control (C0) and treated (P0) shrimp revealed similar bacterial diversities (bands B, C, D and E) with few differences in bands intensities. This type of profile was observed along storage with variations in band intensities in control lot whereas in treated lot, the profile changed with mainly the disappearance of bands B and D and the apparition of a new band (band A).

Hence, TTGE showed that initially Brochothrix was among the major detected microflora and Carnobacterium, was detected with lesser intensity. Both these microflora, maintained in control lot during storage while they were not further detected in treated lot. Thus the antimicrobial activity of the extracts against microbial growth appeared the most effective against Brochothrix and Carnobacterium. For the other microflora, a reduction was seen on not only the rate of increase, but also in the bacterial counts in the treated shrimp during storage.

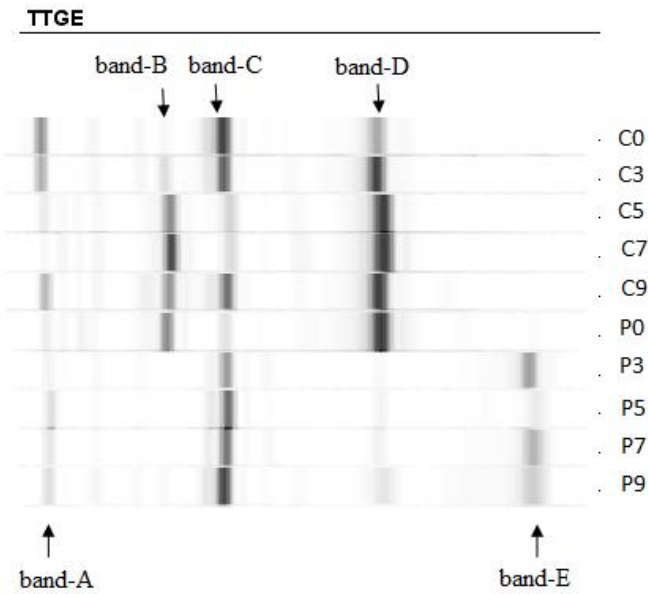

Figure 4: Fingerprints and bacterial population dynamics of peeled shrimps during storage. Digitized TTGE profiles of 16s Rrna Gene V3 Regions obtained by PCR amplification from bacterial DNA of six samples (Day 0, Day 3, Day 5, Day 7, Day 9) from 2 batches (C: Control Shrimps; P: Treated Shrimps) stored at $2^{\circ} \mathrm{C}$. Assignment of PCR-TTGE Bands obtained from shrimp matrix to bacterial reference strain profiles: Band-A, Unassigned; Band-B, Carnobacterium; Band-C, Psychrobacter; Band-D, Brochothrix; and Band-E, Unassigned. The unassigned bands are considered as related to unknown strains.

When growing, the metabolic activity of Brochothrix spoils the product with the emission of off-odours (Jaffrès et al., 2011). Thus the inhibition of Brochothrix in treated shrimps may contribute to explain the extension of sensory shelf-life. Polyphenol treatment by reducing bacterial development as well as the related activity of endogenous enzymes slows down the rate of deterioration during storage. Antimicrobial coatings techniques are commonly applied to improve food safety, including seafood products (Dupard et al., 2006; Jiang et al., 2011; Guo et al., 2013). The polyphenolic extract used in present study seems to be potentially useful for this kind of applications.

\section{Principal component analysis (PCA)}

All the obtained data were submitted to principal component analysis (PCA) in order to assess the effect of the treatment on the biochemical, microbial and sensory quality of shrimp flesh (Fig.5a and 5b). Together, the first two principal components (PC1 and PC2) accounted for $83 \%$ of total system variability. For PC1, the biochemical and bacterial growth variables were positively correlated with the storage time while lipid 
and sensory attributes were negatively correlated with it. For PC2, the polyphenols treatment was positively correlated with sensory analysis. Globally, samples of control and treated shrimps were grouped into two distinct clouds confirming the positive effect of polyphenols treatment on bio-preservation of peeled shrimp during refrigerated storage.
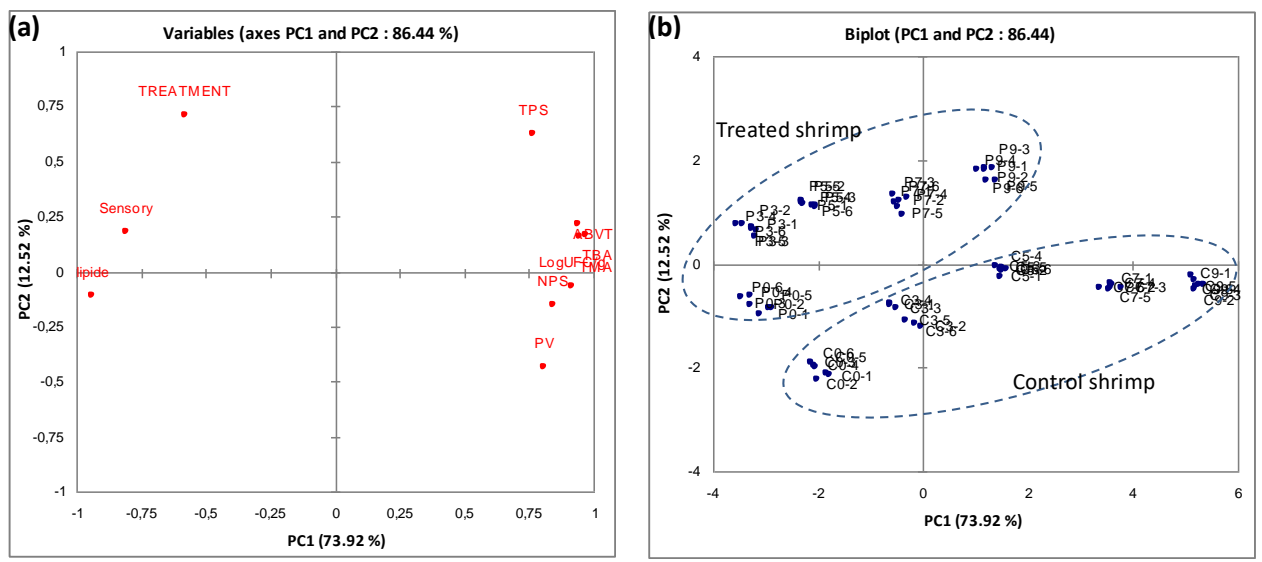

Figure 5: Score (A) and loading (B) Plots from the Principal Component Analysis (PCA) carried out on all variables (Tps: Storage time, TMA, ABVT, NPS, Sensory analysis, Bacterial growth and treatment). Treated (P) and Control groups (C) are encircled.

\section{Conclusion}

Polyphenols extract from cactus peel fruits was evaluated for its antibacterial and antioxidant activities. It appeared to have promising applications in aquatic food processing as the natural antioxidants reduced the final microbial load during refrigerated storage as well as biochemical degradation in peeled shrimps. The use of such extract, either in the frame of sound application in local contexts or in the frame of industrially produced extracts, may also be regarded as a new opportunity for the valorization of an under-exploited agro-resource. In addition, the study of bacterial communities and the PCR-TTGE technique used in this work appeared as an excellent tool to distinguish species that are difficult to enumerate separately by culture-dependent methods and to monitor the evolution of the microbial ecosystem in seafood products during storage. This polyphasic study has improved our knowledge of the spoilage microbiota of peeled shrimp and allowed an objective evaluation of the efficiency of a natural additive

\section{Acknowledgements}

This study was performed in the framework of INSTM's research project 25/TG/05 funded by Tunisian Ministry of Higher Education and Research. The work also benefitted from an SSHN grant supported by the Embassy of France in the frame of institutional bilateral cooperation between INSTM and Ifremer; as well as support from the project BIOVecQ (PS1.3_08) financed by the Cross-border cooperation program Italy-Tunisia in the frame of the European Neighborhood and Partnership Instrument IEVP-2007-2013.

\section{References}

[1] AOAC. Official methods of analysis, 16th ed., Washington DC: Association of Official Chemists, 1998

[2] Attouchi, M. Sadok, S. The effect of powdered thyme sprinkling on quality changes of wild and farmed gilthead sea bream fillets stored in ice. Food Chemistry. 119, 2010, 1527-34. DOI:10.1016/j.foodchem.2009.09.038.

[3] Azeredo, H.M.C. Betalains: properties, sources, applications, and stability - a review. International Journal of Food Science and Technology, 44, 2009, 2365-76

[4] Benner, R.A.J.R. Staruszkiewicz, W.F. Rogers, P.L. And Otwell, W.S. Evaluation of putrescine, cadaverine, and indole as chemical indicators of decomposition in penaeid shrimp. Journal of Food Science, 68, 2003, 2178-85.

[5] Boulares, M. Mankai, M. Sadok, S. and Mnasser, H. Anti-Listerial inhibitory lactic acid bacteria in fresh farmed sea bass (Dicentrarchus labrax) fillets during storage at $4{ }^{\circ} \mathrm{C}$ under vacuum-packed conditions. Journal of Food Safety. DOI: 10.1111/jfs.12323, 2016.

[6] Bouzgarrou, O. El Mzougui, N. and Sadok, S. Smoking and polyphenols' addition to improve freshwater mullet (Mugil cephalus) fillets' quality attributes during refrigerated storage. International Journal of Food Science and Technology. 51, 2015, 268-77. DOI:10.1111/ijfs. 12955

[7] Butera, D. Tesoriere, L. Di. Gaudio, F., Bongiorno, A. Allegra, M. Pintaudi, Am. Kohen, R. and Livrea, M.A. Antioxidant activities of Sicilian prickly pear (Opuntia ficus-indica) fruit extracts and reducing properties of its betalains: betanin and indicaxanthin. Journal of Agricultural and Food Chemistry. 50, 2002, 6895-6901.

[8] Caballero, M.E.L. Gonçalves, A. and Nunes, M.L. Effect Of $\mathrm{CO}_{2} / \mathrm{O}_{2}$-Containing Modified Atmospheres On Packed Deepwater Pink Shrimp (Parapenaeus Longirostris). European Food Research and Technology. 214, 2002, 192-7.

[9] Cadun, A. Cakli, S. and Kisla, D. A Study of Marination Of Deepwater Pink Shrimp (Parapenaeus Longirostris, Lucas, 1846) And Its Shelf Life. Food Chemistry. 90, 2005, 53-9. Doi:10.1016/J. Food chemistry.2004.03.024 
[10] Calo-Mata, P. Arlindo, S. Boehme, K. De Miguel, T. Pascoal, A. and Barros-Velazquez, J. Current Applications And Future Trends Of Lactic Acid Bacteria And Their Bacteriocins For The Biopreservation Of Aquatic Food Products. Food Bioprocess Technology. 1, 2008, 43-63. Doi 10.1007/S11947-007-0021-2

[11] CEC. Decision 95/149/EC of 8 March 1995 fixing the total volatile basic nitrogen (TVB) limit values for certain categories of fishery products and specifying the analysis methods to be used. Commission of the European Community, Brussels, 1995.

[12] Chaijan, M. Benjakul, S. Visessanguan, W. and Faustman, C. Changes Of Lipids In Sardine (Sardinella Gibbosa) Muscle During Iced Storage. Food Chemistry. 99, 2006, 83-91 Doi:10.1016/J.Foodchem.2005.07.022

[13] Chapman, R. and Mckay, J. The Estimation Of Peroxides In Fats And Oils By The Ferric Thiocyanate Method. Journal of the American Oil Chemists' Society. 26, 1949, 360-3.

[14] Dupard, T. Janes, M.E. Beverly, R.L. and Jon, W. Antimicrobial Effect Of Cetylpyridinium Chloride On Listeria Monocytogenes V7 Growth On The Surface Of Raw And Cooked Retail Shrimp. Journal of Food Science. 71, 2006, 241-4.

[15] Eakpetch, P. Benjakul, S. Visessanguan, W. and Kijroongrojana, K. Autolysis Of Pacific White Shrimp (Litopenaeus Vannamei) Meat: Characterization And The Effects Of Protein Additives. Journal of Food Science. 73, 2008, 95-103.

[16] FAO, Food and Agriculture Orginization. Cactus (Opuntia spp.) as forage. Plant Production and Protection Paper (FAO), No. 169: $156 \mathrm{p}, 2002$.

[17] FAO, Food and Agriculture Orginization. Agro-industrial utilization of cactus pear. FAO Rural Infrastructure and Agro-Industries Division, in collaboration with International Technical Cooperation Network on Cactus (FAO-CACTUSNET), Rome, 150 p, 2013.

[18] Feugang, J.M., Konarski, P., Zou, D., Stintzing, F.C. And Zou, C. Nutritional And Medicinal Use Of Cactus Pear (Opuntia Spp.) Cladodes And Fruits. Frontiers in Bioscience. 11, 2006, 2574-89

[19] Folch, J. Lees, M. and Stanley, G.H.S. A Simple Method For The Isolation And Purification Of Total Lipids From Animal Tissue Journal of Biological Chemistry. 226, 1957, 497-509.

[20] Gelssman, T.A. Flavonoid Compounds Tannins Lignins And Related Compounds. In: Florkin M, Stutz Eh, Editors. Pyrrole Pigments, Isoprenoid Compounds and Phenolic Plant Constituents. New York: Elsevier. Chapter 9 P 265, 1963.

[21] Gomez-Guillen, M.C. Martinez-Alvarez, O. Llamas, A. And Montero, P. Melanosis Inhibition And So2 Residual Levels In Shrimps (Parapenaeus Longirostris) After Different Sulfite-Based Treatments. Journal of the Science of Food and Agriculture. 85, 2005, 1143-8.

[22] Gonçalves, A.C., López-Caballero, M.E. and Nunes, M.L. Quality Changes Of Deepwater Pink Shrimp (Parapenaeus Longirostris) Packed In Modified Atmosphere. Journal of Food Science. 68, 2003, 2586-90.

[23] Gram, L. Ravn, L. Rasch, M. Bruhn, J.B. Christensen, A.B. and Givskov, M. Food Spoilage-Interactions Between Food Spoilage Bacteria. International Journal of Food Microbiology. 78, 2002, 79-97.

[24] Gregersen, T. Rapid Method for Distinction Of Gram-Negative From Gram-Positive Bacteria. Applied Microbiology and Biotechnology. 5, 1978, 123-7.

[25] Guo, M. Jin, T.Z., Scullen, O.J. and Sommers, C.H. Effects of Antimicrobial Coatings and Cryogenic Freezing On Survival And Growth Of Listeria Innocua On Frozen Ready-To-Eat Shrimp During Thawing. Journal of Food Science. 78, 2013 , $195-200$.

[26] Han, K.I. Kim, Y.H. Hwang, S.G. Jung, E.G. Patnaik, B.B. Han, Y.S. Nam, K.W. Kim, W.J. and Han, M.D. Bacterial Community Dynamics Of Salted And Fermented Shrimp Based On Denaturing Gradient Gel Electrophoresis. Journal of Food Science. 79, 2014, 516-522.

[27] He, Q.Q. Yang, L. Zhang, J.Y. Ma, J.N. And Ma, C.M. Chemical Constituents Of Gold-Red Apple And Their A-Glucosidase Inhibitory Activities. Journal of Food Science. 79, 2014, 1970-83.

[28] Huang, J. Chen, Q. Qiu, M. And Li, S. Chitosan-Based Edible Coatings For Quality Preservation Of Postharvest Whiteleg Shrimp (Litopenaeus Vannamei). Journal of Food Science. 77, 2012, 491-6.

[29] Huidobro, A. Caballero, M.E.L. And Mendes, R. Onboard Processing Of Deepwater Pink Shrimp (Parapenaeus Longirostris) With Liquid Ice: Effect On Quality. European Food Research and Technology. 214, 2002, 469-75.

[30] Jaffrès, E. Lalanne, V. Macé, S. Cornet, J. Cardinal, M. Sérot, T. And Others. Sensory Characteristics Of Spoilage And Volatile Compounds Associated With Bacteria Isolated From Cooked And Peeled Tropical Shrimps Using Spme-Gc-Ms Analysis. International Journal of Food Microbiology. 147, 2011, 195-202

[31] Jaffres, E. Sohier, D. Leroi, F. Pilet, M.F. Prevost, H. Joffraud, J.J. And Dousset, X. Study Of The Bacterial Ecosystem In Tropical Cooked And Peeled Shrimps Using A Polyphasic Approach. International Journal of Food Microbiology. 131, $2009,20-9$.

[32] Jana, S. Nutraceutical And Functional Properties Of Cactus Pear (Opuntia Spp.) And Its Utilization For Food Applications. Journal of Engineering Research Study Iii: 60-6, 2012

[33] Jiang, M., Liu, S. And Wang, Y. Effects Of Antimicrobial Coating From Catfish Skin Gelatin On Quality And Shelf Life Of Fresh White Shrimp (Penaeus Vannamei). Journal of Food Science. 76, 2011, 204-9.

[34] Kaewmanee, T. Benjakul, S. And Visessanguan, A. Protein Hydrolysate Of Salted Duck Egg White As A Substitute Of Phosphate And Its Effect On Quality Of Pacific White Shrimp (Litopenaeus Vannamei). Journal of Food Science. 74, $2009,351-61$.

[35] Khatabi, O. Hanine, H. Elothmani, D. And Hasib, A. Extraction And Determination Of Polyphenols And Betalain Pigments In The Moroccan Prickly Pear Fruits (Opuntia Ficus Indica). Arabian Journal of Chemistry, 2011.

[36] Knittweis, L. Arneri, E. Ben Meriem, S., Dimech, M. Fiorentino, F., Gancitano, V. Jarboui, O., Mbarek, K.B. And Ceriola, L. Stock Status And Potential Yield Of Deep Water Rose Shrimp (Parapenaeus Longirostris, Lucas 1846) In The South-Central Mediterranean Sea. Med-Sud-Med Technical Documents. No 28: 15 Pp, 2013.

[37] Laursen, B.G. Leisner, J.J. And Dalgaard, P. Carnobacterium Species: Effect of Metabolic Activity And Interaction With Brochothrix Thermosphacta On Sensory Characteristics Of Modified Atmosphere Packed Shrimp. Journal of Agricultural and Food Chemistry. 54, 2006, 3604-11

[38] Ma, J.N. Wang, S.L. Zhang, K. Wu, Z.G. Hattori, M. Chen, G.L. and Ma, C.M. Chemical Components And Antioxidant Activity Of The Peels Of Commercial Apple-Shaped Pear (Fruit Of Pyrus Pyrifolia Cv. Pingguoli). Journal of Food Science. 77, 2012.1970-83.

[39] Mace, S. Cornet, J. Chevalier, F. Cardinal, M. Pilet Dousset, M.F.X. And Joffraud, J.J. Characterisation Of The Spoilage Microbiota In Raw Salmon (Salmo Salar) Steaks Stored Under Vacuum Or Modified Atmosphere Packaging Combining Conventional Methods And PCR-TTGE. Food Microbiology. 30, 2012, 164-72.

[40] Maqsood, S. Benjakul, S. And Shahidi, F. Emerging Role Of Phenolic Compounds As Natural Food Additives In Fish And Fish Products. Critical Reviews in Food Science and Nutrition. 53, 2012, 162-79.

[41] Mejlholm, O., Boknaes, N. and Dalgaard, P. Shelf Life and Safety Aspects Of Chilled Cooked And Peeled Shrimps (Pandalus Borealis) In Modified Atmosphere Packaging. Journal of Applied Microbiology. 99, 2005, 66-76.

[42] Metcalfe, L.D. Schimitz, A.A. and Pelka, J.R. Rapid Preparation Of Fatty Acids Esters From Lipids For Gas Chromatographic Analysis. Annex Chemistry. 38, 1966, 524-35. 
[43] Montero, P., Martínez-Álvarez, O. and Gómez-Guillén, M.C. Effectiveness Of Onboard Application Of 4-Hexylresorcinol In Inhibiting Melanosis In Shrimp (Parapenaeus Longirostris). Journal of Food Science. 69, 2004, 647-8.

[44] Nirmal, N.P. and Benjakul, S. Effect Of Green Tea Extract In Combination With Ascorbic Acid On The Retardation Of Melanosis And Quality Changes Of Pacific White Shrimp During Iced Storage. Food and Bioprocess Technology. 5, 2010, 1-11. Doi 10.1007/S11947-010-0483-5

[45] Oksuz, A. Ozyilmaz, A. Aktas, M. Gercek, G. and Motte, J. A Comparative Study On Proximate, Mineral And Fatty Acid Compositons Of Deep Seawater Rose Shrimp (Parapenaeus Longirostris, Lucas 1846) And Golden Shrimp (Plesionika Martia, A. Milne-Edwards, 1883). Journal of Animal and Veterinary Advances. 8, 2009, 183-9.

[46] Ortega-Ramirez, L.A. Rodriguez-Garcia, I. Leyva, J.M. Cruz-Valenzuela, M.R. Silva-Espinoza, B.A. Gonzalez-Aguilar, G.A. Siddiqui, M.W. and Ayala-Zavala, J.F. Potential Of Medicinal Plants As Antimicrobial And Antioxidant Agents In Food Industry: A Hypothesis. Journal of Food Science. 79, 2014, R129-137. Doi: 10.1111/1750-3841.12341

[47] Parayre, S. Falentin, H. Madec, M.N. Sivieri, K., Le Dizes, A.S. Sohier, D. And Lortal, S. Easy Dna Extraction Method And Optimisation Of Pcr-Temporal Temperature Gel Electrophoresis To Identify The Predominant High And Low Gc-Content Bacteria From Dairy Products. Journal of Microbiological Methods. 69, 2007, 431-41.

[48] Peryam, D.R. and Pilgrim, F.J. Hedonic Scale Method Of Measuring Food Preferences. Food Technology. 11, 1957, 9-14.

[49] Qian, Y.F., Yang, S.P., Jing, X., Qing, X. And Zhi-Li, G. Impact Of The O2 Concentrations On Bacterial Communities And Quality Of Modified Atmosphere Packaged Pacific White Shrimp (Litopenaeus Vannamei). Journal of Food Science. 78, $2013,878-84$.

[50] Richard, T. Lefeuvre, D. Descendit, A. Quideau, S. and Monti, J.P. Recognition Characters In Peptide-Polyphenol Complex Formation. Biochimica Biophysica Acta. 1760, 2006, 951-8.

[51] Ruiz-Capillas, C. and Horner, W.F.A. Determination Of The Trimethylamine And Total Volatile Basic Nitrogen In Flesh Fish By Flow Injection Analysis. Journal of the Science of Food and Agriculture. 79, 1999, 1982-6.

[52] Ruiz-Capillas, C. And Moral, A. Free Amino Acids In Hake Stored In Bulk And Packed In A Combined System Of Atmospheres. Journal of Food Science. 68, 2003, 105-10.

[53] Sadok, S., Abdelmoulah, A.And El Abed, A. Combined Effect Of Sepia Soaking And Temperature On The Shelf Life Of Peeled Shrimp Penaeus Keraturus. Food Chemistry. 88, 2004, 115-22.

[54] Sadok, S., Uglow, R.F.And Haswell, S.J. Determination of Ninhydrine Positive Substances In Haemolymph And Seawater. Analyst. 120, 1995, 2097-99.

[55] Sadok, S., Uglow, R.F. and Haswell, S.J. Determination Of Trimethylamine In Fish By Flow Injection Analysis. Analytica Chimica Acta. 321, 1996, 69-74

[56] Sawaya, W.N. Khatchadourian, H.A. Safi, W.M. and Al-Muhammad, H.M. Chemical Characterization Of Prickly Pear Pulp, Opuntia Ficus-Indica, And The Manufacturing Of Prickly Pear Jam. International Journal of Food Science and Technology. 18, 1983, 183-93. Doi: 10.1111/J.1365-2621.1983.Tb00259.X

[57] Singleton, V.L. Orthofe, R. And Lamuela-Raventos, R.M. Analysis Of Total Phenols And Other Oxidation Substrates And Antioxidants By Means Of Folin-Ciocalteu Reagent. Methods in Enzymology. 299, 1999, 152-178.

[58] Snellings, S.L. Takenaka, N.E., Kim-Hayes, Y. and Miller, D.W. Rapid Colorimetric Method to Detect Indole In Shrimp With Gas Chromatography Mass Spectrometry Confirmation. Journal of Food Science. 68, 2003, 1548-53.

[59] Souza, M.P. Vaz, A.F.M. Silva, H.D., Cerqueira, M.A. Vincente, A.A. and Carneiro-Da-Cunha, M.G. Development And Characterization Of An Active Chitosan-Based Film Containing Quercetin. Food and Bioprocess Technology. 8, 2015, 2183-91. Doi 10.1007/S11947-015-1580-2.

[60] Sundararajan, S., Prudente, A. Bankston, J.D. King, J.M. Wilson, P. And Sathivel, S. Evaluation Of Green Tea Extract As A Glazing Material For Shrimp Frozen By Cryogenic Freezing.Journal of Food Science 76, 2011, 511-8.

[61] Thepnuan, R. Benjakul, S. and Visessanguan, W. Effect Of Pyrophosphate And 4-Hexylresorcinol Pretreatment On Quality Of Refrigerated White Shrimp (Litopenaeus Vannamei) Kept Under Modified Atmosphere Packaging. Journal of Food Science. 73 , 2008, 124-33.

[62] Thompson, J.D. Higgins, D.G. and Gibson, T.J. Clustal W: Improving The Sensitivity Of Progressive Multiple Sequence Alignment Through Sequence Weighting, Position Specific Gap Penalties And Weight Matrix Choice. Nucleic Acids Research. 22, 1994, 467380 .

[63] Van Spreekens, K.J.A. The Suitability Of A Modification Of Long And Hammer's Medium For The Enumeration Of More Fastidious Bacteria From Fresh Fishery Products. Archiv für Lebensmittelhygiene. 25, 1974, 213-19.

[64] Weisburg, W.G. Barns, S.M. Pelletier, D.A. And Lane, D.J. 16s Ribosomal DNA Amplification For Phylogenetic Study. Journal of Bacteriology. 173, 1991, 697-703.

[65] Yerlikaya, P. Gokoglu, N. and Topuz, O.K. Use Of Natural Plant Extracts In Batter Coating Of Shrimp And Their Effects On The Quality Of Shrimp During Frozen Storage. Journal of Food Processing and Preservation. 34, 2010, 127-38.

[66] Zeng, Q.Z. Thorarinsdottir, K.A. and Olafsdottir, G. Quality Changes Of Shrimp (Pandalus Borealis) Stored Under Different Cooling Conditions. Journal of Food Science. 70, 2005, 459-66.

[67] Zhou, S. Sheen, S. Pang, Y.H., Liu, L. and Yam, K.L. Antimicrobial Effects Of Vapor Phase Thymol Modified Atmosphere, And Their Combination Against Salmonella Spp. On Raw Shrimp. Journal of Food Science. 78, 2013, 725-30. 